\title{
Quaternary Ammonium Polyethyleneimine: Antibacterial Activity
}

\author{
Ira Yudovin-Farber, ${ }^{1}$ Jacob Golenser, ${ }^{2}$ Nurit Beyth, ${ }^{3}$ Ervin I. Weiss, ${ }^{3}$ and Abraham J. Domb ${ }^{1}$ \\ ${ }^{1}$ Department of Medicinal Chemistry and Natural Products, School of Pharmacy, Faculty of Medicine, \\ The Hebrew University of Jerusalem, Jerusalem 91120, Israel \\ ${ }^{2}$ Department of Parasitology, The Kuvin Centre for the Study of Infectious and Tropical Diseases, \\ The Hebrew University of Jerusalem, Jerusalem 91120, Israel \\ ${ }^{3}$ Department of Prosthodontics, Faculty of Dentistry, The Hebrew University of Jerusalem, Jerusalem 91120, Israel
}

Correspondence should be addressed to Abraham J. Domb, avid@ekmd.huji.ac.il

Received 14 July 2009; Revised 7 March 2010; Accepted 8 May 2010

Academic Editor: Alan Fuchs

Copyright (C) 2010 Ira Yudovin-Farber et al. This is an open access article distributed under the Creative Commons Attribution License, which permits unrestricted use, distribution, and reproduction in any medium, provided the original work is properly cited.

\begin{abstract}
Quaternary ammonium polyethyleneimine- (QA-PEI-) based nanoparticles were synthesized using two synthetic methods, reductive amination and N-alkylation. According to the first method, QA-PEI nanoparticles were synthesized by cross-linking with glutaraldehyde followed by reductive amination with octanal and further N-methylation with methyl iodide. The second method is based on crosslinking with dialkyl halide followed by $\mathrm{N}$-alkylation with octyl halide and further N-methylation with methyl iodide. QA-PEI nanoparticles completely inhibited bacterial growth ( $>10^{6}$ bacteria), including both Gram-positive, that is, Staphylococcus aureus at $80 \mu \mathrm{g} / \mathrm{mL}$, and Gram-negative, that is, Escherichia coli at $320 \mu \mathrm{g} / \mathrm{mL}$. Activity analysis revealed that the degree of alkylation and N-methylation of the QA-PEI nanoparticles plays a significant role in antibacterial activity of the reagent. The most potent compound was octyl alkylated QA-PEI alkylated at 1:1 mole ratio (primary amine of PEI monomer units/alkylating agent). Also, cytotoxicity studies on MAT-LyLu and MBT cell lines were performed with QA-PEI nanoparticles. These findings confirm previous reports that polycations bearing quaternary ammonium moieties inhibit bacterial growth in vitro and have a potential use as additives in medical devices which need antibacterial properties.
\end{abstract}

\section{Introduction}

During the last two decades continuous efforts have been made to develop polymers with antimicrobial properties. Positive charge and hydrophobic nature of the antibacterial reagent are important factors of cationic disinfectants [1]. Quaternary ammonium compounds have a broad spectrum of antimicrobial activity against both Gram-positive and Gram-negative bacteria [2]. As compared with smallmolecule antimicrobial agents, polymeric antimicrobials have advantages, such as that they are nonvolatile, chemically stable, have long-term antimicrobial activity, and are hard to permeate through the skin [3-5]. Distinctively, polycationic antimicrobials, bearing quaternary ammonium moieties, have high charge density exhibiting high antimicrobial activity [6].
Most of these compounds bearing quaternary ammonium groups appear to act by interacting with and disrupting negatively charged bacterial cell membrane followed by release of $\mathrm{K}^{+}$ions and other cytoplasmic constituents, resulting in immediate death of the bacterial cell. In contrast to the soluble polycations, insoluble quaternary ammonium macromolecules act on the surface of the microbial cell and display their antimicrobial activity only on contact without permeation [1]. An alternative mechanism of action was proposed by Kügler et al. for cationic surfaces which appear to induce an ion exchange between the positive charges and cations within the membrane [7]. Upon approaching a cationic surface, the structurally essential divalent cations of the membrane are relieved of their role in charge neutralization of the membrane components and are thus free to diffuse out of the membrane. The loss of these 
structural cations results in a loss of membrane integrity [7].

A number of polycations possessing antimicrobial properties were developed for this purpose including ion exchange fibers [8], alkoxysilanes [9], soluble and insoluble pyridinium-type polymers $[10,11]$, polyionenes [12], polymer surfaces derivatized with poly(vinyl-N-pyridinium) $[13,14]$, and immobilized $\mathrm{N}$-alkylated polyethyleneimine [15-17].

Polyethyleneimine (PEI) is a synthetic polymer prepared from aziridine by cationic polymerization. Its structure contains primary, secondary, and tertiary amino groups due to chain transfer reactions. The amino group ratio is $1: 2: 1$ (i.e., $25 \%$ of primary amines, $50 \%$ of secondary amines, and $25 \%$ of tertiary amines). The amino groups of PEI are chemically reactive and consequently enable a wide variety of chemical modifications which provide PEI with appropriate physicochemical properties. Because of its positive charge and hydrophobicity, alkylated PEI has already attracted attention as a possible antimicrobial agent. For instance, a novel, nonrelease strategy for creating bactericidal surfaces which involves covalent coating with long hydrophobic polycationic chains is based on polyethyleneimine. Thus, coating with polycation was found effective against a variety of Gram-positive and Gram-negative bacteria [15-17]. In addition, Hilal et al. reported on strong antibacterial effect against $E$. coli achieved with polyvinylidene fluoride microfiltration membranes which were modified with PEI using interfacial polymerisation method [18].

Prompted by these results, we examined the antibacterial activity of quaternary ammonium polyethyleneimine (QAPEI) nanoparticles prepared via two synthetic methods including reductive amination and $\mathrm{N}$-alkylation followed by N-methylation step. Of note, QA-PEI has been studied as antibacterial additive incorporated in clinically used restorative composite resins [19]. We have also shown that octyl alkylated QA-PEI based nanoparticles embedded in a restorative composite resin at $1 \% \mathrm{w} / \mathrm{w}$ demonstrated strong antibacterial effect against $S$. mutans which lasted for at least 3 months [20]. Moreover, incorporation of QA-PEI based nanoparticles in dental composite resin at $1 \% \mathrm{w} / \mathrm{w}$ was biocompatible [21].

Here we report on a series of QA-PEI nanoparticles which inhibit bacterial growth $\left(>10^{6}\right.$ bacteria). The purpose of the present study was to evaluate the QA-PEI nanoparticle structure-activity relationship with respect to the degree of alkylation, N-methylation, PEGylation effect and counter ion, which can play a significant role in the antibacterial activity of the tested nanoparticles. The most potent compound was octyl alkylated QA-PEI alkylated at $1: 1$ mole ratio (primary amine of PEI monomer units/alkylating agent).

\section{Materials and Methods}

2.1. Materials. Polyethyleneimine (PEI) of molecular weight of $750-\mathrm{kDa}(50 \% \mathrm{w} / \mathrm{w}$ aqueous solution) purchased from Fluka (Rehovot, Israel) was freeze-dried before use. Bromooctane, iodooctane, dibromopentane, diiodopentane, iodomethane, sodium cyanoborohydride, octanal, polyethylene glycol monomethyl ether $\left(\mathrm{MPEG}_{2000}\right)$, p-nitrophenyl chloroformate, and sodium bicarbonate were all purchased from Sigma-Aldrich (Rehovot, Israel) and used without further purification. Silver nitrate $\left(\mathrm{AgNO}_{3}\right)$ was purchased from Baker (Jerusalem, Israel). Aqueous solution of glutaraldehyde $(25 \%$ w/w) was purchased from Frutarom (Haifa, Israel). All solvents and reagents were of analytical grade and were used as indicated.

IR spectra were recorded on a Perkin Elmer System 2000 FT-IR. ${ }^{1} \mathrm{H}-\mathrm{NMR}$ spectra $\left(\mathrm{DMSO}-\mathrm{d}_{6}\right.$ or $\mathrm{CDCl}_{3}$ ) were obtained on a Varian 300-MHz spectrometer in $5 \mathrm{~mm}$ o.d. tubes. $\mathrm{CDCl}_{3} / \mathrm{DMSO}-\mathrm{d}_{6}$ containing tetramethylsilane served as solvent, and shift reference particle size was determined by dynamic light scattering (DLS) at $25^{\circ} \mathrm{C}$ using the particle sizer ALV-NIBS/HPPS with ALV-5000/EPP multiple digital correlator (ALV-Laser Vertriebsgesellschaft GmbH, Langen, Germany). The particle sizer used a $3 \mathrm{~mW} \mathrm{HeNe}$ laser (wavelength $632.8 \mathrm{~nm}$ ) and a scattering angle of $173^{\circ}$. The measurements were carried out in disposable plastic cuvettes (Sarstedt AG \& Co., Nümbrecht, Germany), and samples were dispersed in double deionized water. The experimental data were analyzed using the ALV-5000/E software, taking the temperature correction of the viscosity into account. Degree of alkylation and methylation was estimated by elemental microanalysis of nitrogen $(\% \mathrm{~N})$, carbon $(\% \mathrm{C})$, and iodine (\%I) using a Perkin-Elmer 2400/II CHN analyzer. Zeta potential was measured using a Zetasizer 2000 (Malvern, UK). Measurements were done in DDW in triplicate. Optical density measurements were made using spectrophotometer (VERSAmax, Molecular Devices Corporation, CA, USA). Multiwell plates were purchased from Nunclon (Nunc, Copenhagen, Denmark). Tryptic Soy Broth (TSB) and Lambda Broth (LB) were purchased from Becton (Dickinson and Company).

2.1.1. Bacteria. Staphylococcus aureus (S. aureus) strain ATCC 29213 and Escherichia coli (E. coli) strain K12 MG1655 were selected for the bacterial inhibition study and grown in a tube containing Tryptic Soy Broth (TSB, Becton, Dickinson and Company), and Lambda Broth (LB, Becton, Dickinson and Company), respectively, at $37^{\circ} \mathrm{C}$.

\subsection{Methods}

2.2.1. Synthesis of Quaternary Ammonium PEI-Based Nanoparticles via Reductive Amination. PEI (10 g, $0.23 \mathrm{~mol}$ of monomer units) was dissolved in $100 \mathrm{~mL}$ of absolute ethanol. Glutaraldehyde solution $(230 \mu \mathrm{l})$ was added at 1:0.01 mole ratio (primary amine of PEI monomer units/glutaraldehyde). The crosslinking reaction was carried out at room temperature for 6 hours.

$\mathrm{N}$-alkylation was conducted as follows: octanal was added at $1: 1,1: 0.75,1: 0.5$, and $1: 0.25$ mole ratio (primary amine of PEI monomer units/octanal, respectively; eventually leading to the 4 compounds no. A, no. B, no. $\mathrm{C}$ and no. D). The alkylation step was carried out at room temperature for 24 hours. The resulting yellow 
suspension was reduced with sodium cyanoborohydride added at 1:0.33 mole ratio (octanal/ $\mathrm{NaCNBH}_{3}$ ) for 24 hours at room temperature. Methylation was carried out with $43 \mathrm{~mL}$ of methyl iodide $(0.69 \mathrm{~mol})$ which was added at $1: 3$ mole ratio (monomer units of PEI /methyl iodide) at $42^{\circ} \mathrm{C}$ for 48 hours. During the methylation step, yellow precipitate was formed. An equivalent amount of sodium bicarbonate $(0.23 \mathrm{~mol}, 19 \mathrm{~g})$ was added to collect released HI during methylation step. Neutralization was continued at the same conditions for additional 24 hours. The precipitated crude was allowed to reach room temperature and washed with hexane and double deionized water (DDW) to remove traces of unreacted octanal, methyl iodide, sodium bicarbonate, and sodium iodide and then was freeze-dried. The purification step was repeated with additional amounts of hexane and DDW, and then freeze-dried. Average yield 75\% ( $\mathrm{mol} / \mathrm{mol})$.

FT-IR (alkylated PEI nanoparticles before reduction, $\mathrm{KBr}): 3400 \mathrm{~cm}^{-1}(\mathrm{~N}-\mathrm{H}), 2927 \mathrm{~cm}^{-1}$ and $2852 \mathrm{~cm}^{-1}(\mathrm{C}-\mathrm{H})$, $1617 \mathrm{~cm}^{-1}(\mathrm{~N}-\mathrm{H}$, small band $), 1641 \mathrm{~cm}^{-1}(\mathrm{C}=\mathrm{N})$, and $1464 \mathrm{~cm}^{-1}(\mathrm{C}-\mathrm{H})$.

FT-IR (QA-PEI nanoparticles, $\mathrm{KBr}): 3440 \mathrm{~cm}^{-1}(\mathrm{~N}-\mathrm{H})$, $2953 \mathrm{~cm}^{-1}, 2924 \mathrm{~cm}^{-1}$, and $2852 \mathrm{~cm}^{-1}(\mathrm{C}-\mathrm{H}), 1617 \mathrm{~cm}^{-1}$ ( $\mathrm{N}-\mathrm{H}$, small band), $1465 \mathrm{~cm}^{-1}(\mathrm{C}-\mathrm{H})$, and $952 \mathrm{~cm}^{-1}$ quaternary nitrogen.

${ }^{1} \mathrm{H}-\mathrm{NMR}$ (cross-linked PEI nanoparticles, $\mathrm{CDCl}_{3}$ ): $1.4 \mathrm{ppm}(\mathrm{m}, 4 \mathrm{H}$, glutaraldehyde protons $), 1.5 \mathrm{ppm}(\mathrm{m}, 2 \mathrm{H}$, glutaraldehyde protons), $2.3-3 \mathrm{ppm}$ (m, $4 \mathrm{H}$ of PEI protons), and $7.5 \mathrm{ppm}(\mathrm{m}, 2 \mathrm{H}$, glutaraldehyde imine protons).

${ }^{1} \mathrm{H}$-NMR (cross-linked PEI-octyl nanoparticles (reduced), $\left.\mathrm{CDCl}_{3}\right): 0.8 \mathrm{ppm}\left(\mathrm{t}, 3 \mathrm{H}, \mathrm{CH}_{3}\right.$,octyl protons), $1.23 \mathrm{ppm}\left(\mathrm{m}, 10 \mathrm{H},-\mathrm{CH}_{2-}\right.$, octyl protons $), 1.4 \mathrm{ppm}(\mathrm{m}, 2 \mathrm{H}$, $-\mathrm{CH}_{2}-$, octyl protons), and $2.4-2.7 \mathrm{ppm}\left(\mathrm{m}, 4 \mathrm{H},-\mathrm{CH}_{2}-\right.$, PEI protons and $2 \mathrm{H},-\mathrm{CH}_{2}-$ of octyl protons).

${ }^{1} \mathrm{H}$-NMR (QA-PEI nanoparticles, DMSO- $\mathrm{d}_{6}$ ): $0.85 \mathrm{ppm}$ (t, $3 \mathrm{H}, \mathrm{CH}_{3}$, octyl protons), $1.22 \mathrm{ppm}\left(\mathrm{m}, 10 \mathrm{H},-\mathrm{CH}_{2}-\right.$, octyl protons), $1.7 \mathrm{ppm}(\mathrm{m}, 2 \mathrm{H}, \mathrm{CH}$, octyl protons), and 2.6$4.4 \mathrm{ppm}(\mathrm{m}$, methyl of quaternary amine, $4 \mathrm{H}$ of $\mathrm{PEI}$ and $2 \mathrm{H}$ of the octyl chain).

2.2.2. Synthesis of the Quaternary Ammonium Polyethyleneimine-Based (QA-PEI) Nanoparticles via N-Alkylation. PEI ( $10 \mathrm{~g}, 0.23 \mathrm{~mol}$ of monomer units) was dissolved in $100 \mathrm{~mL}$ of absolute ethanol. Dibromopentane was added at 1:0.04 mole ratio (monomer units of PEI/dibromopentane). The crosslinking reaction was carried out under reflux for 24 hours.

$\mathrm{N}$-alkylation was conducted as follows: octyl halide was added at 1:1 mole ratio (primary amine of PEI monomer units/octyl halide) to the same flask. The alkylation was carried out under reflux conditions for 24 hours. Excess $\mathrm{NaHCO}_{3}$ (1.25 equimolar of octyl halide) was slowly added to neutralize the released acid. Neutralization reaction was continued for 24 hours at the same conditions.

$\mathrm{N}$-methylation was conducted as follows: $43 \mathrm{~mL}$ of methyl iodide $(0.69 \mathrm{~mol})$ was added to the same flask at $1: 3$ mole ratio (monomer units of $\mathrm{PEI} /$ methyl iodide). Methylation was continued at $42^{\circ} \mathrm{C}$ for 48 hours. An equivalent amount of sodium bicarbonate $(0.23 \mathrm{~mol}, 19 \mathrm{~g})$ was slowly added to collect released HI during methylation step. Neutralization was continued under the same conditions for additional 24 hours. Formed NaI salt and excess of unreacted $\mathrm{NaHCO}_{3}$ were discarded by decantation, and the liquid portion was precipitated in $300 \mathrm{~mL}$ of DDW, washed with hexane to remove traces of unreacted octyl halide, methyl iodide and with DDW to remove inorganic salts, and freeze-dried. The purification step was repeated with additional amounts of hexane and DDW, and freeze-dried. Average yield: 70\% ( $\mathrm{mol} / \mathrm{mol})$.

FT-IR (alkylated PEI nanoparticles, $\mathrm{NaCl}$ ): $3480 \mathrm{~cm}^{-1}$ $(\mathrm{N}-\mathrm{H}), \quad 2950 \mathrm{~cm}^{-1}, \quad 2930 \mathrm{~cm}^{-1}$, and $2850 \mathrm{~cm}^{-1}(\mathrm{C}-\mathrm{H})$, $1635 \mathrm{~cm}^{-1}\left(\mathrm{~N}-\mathrm{H}\right.$, small band), and $1454 \mathrm{~cm}^{-1}(\mathrm{C}-\mathrm{H})$.

FT-IR (QA-PEI nanoparticles, $\mathrm{KBr}): 3440 \mathrm{~cm}^{-1}(\mathrm{~N}-\mathrm{H})$, $2956 \mathrm{~cm}^{-1}, 2926 \mathrm{~cm}^{-1}$, and $2853 \mathrm{~cm}^{-1}(\mathrm{C}-\mathrm{H}), 1617 \mathrm{~cm}^{-1}$ (N-H, small band), $1465 \mathrm{~cm}^{-1}(\mathrm{C}-\mathrm{H})$, and $967 \mathrm{~cm}^{-1}$ quaternary nitrogen.

${ }^{1} \mathrm{H}-\mathrm{NMR}$ (cross-linked PEI nanoparticles, $\mathrm{CDCl}_{3}$ ): $1.43 \mathrm{ppm}(\mathrm{m}, 2 \mathrm{H}$, alkyl protons), $1.58 \mathrm{ppm}(\mathrm{m}, 4 \mathrm{H}$, alkyl protons), and 2.1-3 ppm (m, $4 \mathrm{H}$ of PEI protons and $4 \mathrm{H}$ of alkyl protons).

${ }^{1} \mathrm{H}-\mathrm{NMR}$ (cross-linked PEI-octyl alkylated nanoparticles, $\left.\mathrm{CDCl}_{3}\right): 0.86 \mathrm{ppm}$ (t, $3 \mathrm{H}, \mathrm{CH}_{3}$,octyl protons), $1.24 \mathrm{ppm}$ (m, $10 \mathrm{H},-\mathrm{CH}_{2-}$, octyl protons), $1.39 \mathrm{ppm}\left(\mathrm{m}, 2 \mathrm{H},-\mathrm{CH}_{2}-\right.$, octyl protons), and $2.36-2.7 \mathrm{ppm}\left(\mathrm{m}, 4 \mathrm{H},-\mathrm{CH}_{2}-\right.$, PEI protons and $2 \mathrm{H}$ of octyl protons).

${ }^{1} \mathrm{H}-\mathrm{NMR}$ (QA-PEI, DMSO- $\left.\mathrm{d}_{6}\right): 0.845 \mathrm{ppm}\left(\mathrm{t}, 3 \mathrm{H}, \mathrm{CH}_{3}\right.$, octyl protons), $1.24 \mathrm{ppm}\left(\mathrm{m}, 10 \mathrm{H},-\mathrm{CH}_{2}-\right.$, octyl protons), $1.65 \mathrm{ppm}(\mathrm{m}, 2 \mathrm{H}, \mathrm{CH}$, octyl protons), and 3.2-3.6 ppm (m, methyl of quaternary amine, $4 \mathrm{H}$ of PEI and $2 \mathrm{H}$ of the octyl chain).

The primary amine content after alkylation step was determined by the trinitrobenzene sulfonic acid (TNBS) method [22].

\subsubsection{Exchange Reaction of Iodide Form of Quaternary Ammo-} nium Polyethyleneimine (QA-PEI) Nanoparticles to Nitrate Form. $1 \mathrm{~g}$ of the previously prepared QA-PEI nanoparticles $\left(\mathrm{Mw}_{\text {average }}=223 \mathrm{~g} / \mathrm{mol}, 4.5 \mathrm{mmol}\right)$ was dispersed in $100 \mathrm{~mL}$ of double deionized water (DDW). $50 \mathrm{~mL}$ of $1.8 \mathrm{M}$ of $\mathrm{AgNO}_{3}$ solution was added dropwise to QA-PEI dispersion. Exchange reaction was continued for 2 hours at $70^{\circ} \mathrm{C}$. AgI salt was discarded by filtration. Filtrate was poured into a dialysis membrane (3500 cutoff, Membrane Filtration Products, Inc., San Antonio, TX) and dialyzed against DDW at $4^{\circ} \mathrm{C}$ for 3 days. The dialysate was lyophilized to dryness. Yield: $50 \%$ $(\mathrm{w} / \mathrm{w})$, elemental analysis of I (\%) before exchange reaction: 54.26, elemental analysis of I (\%) after exchange reaction: 4.65 .

\subsubsection{Exchange Reaction of Iodide Form of QA-PEI Nanoparti-} cles to Acetate Form. $1 \mathrm{~g}$ of QA-PEI nanoparticles ( $\mathrm{Mw}_{\text {average }}$ $=223 \mathrm{~g} / \mathrm{mol}, 4.5 \mathrm{mmol}$ ) was dispersed in $60 \mathrm{~mL}$ of $1 \mathrm{~N}$ acetic acid. The resulting dispersion was stirred for 3 hours at room temperature, then poured into a dialysis membrane ( 3500 cutoff cellulose tubing), and dialyzed against DDW at $4^{\circ} \mathrm{C}$ for 3 days. The dialysate was lyophilized to dryness. Yield: 50\% $(\mathrm{w} / \mathrm{w})$, elemental analysis of I (\%) before exchange reaction: 


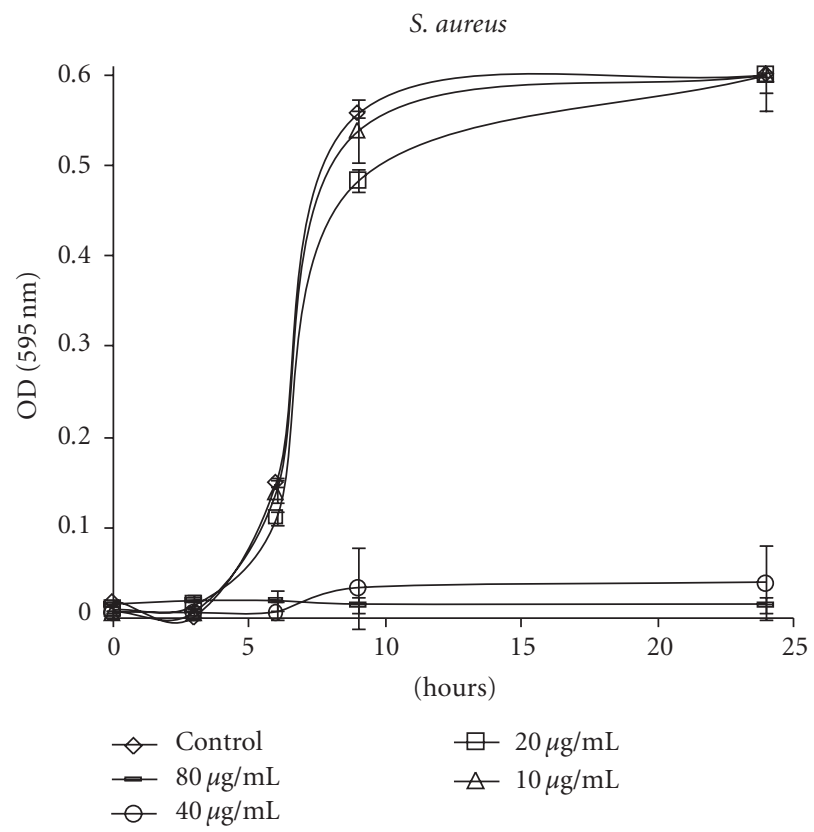

(a)

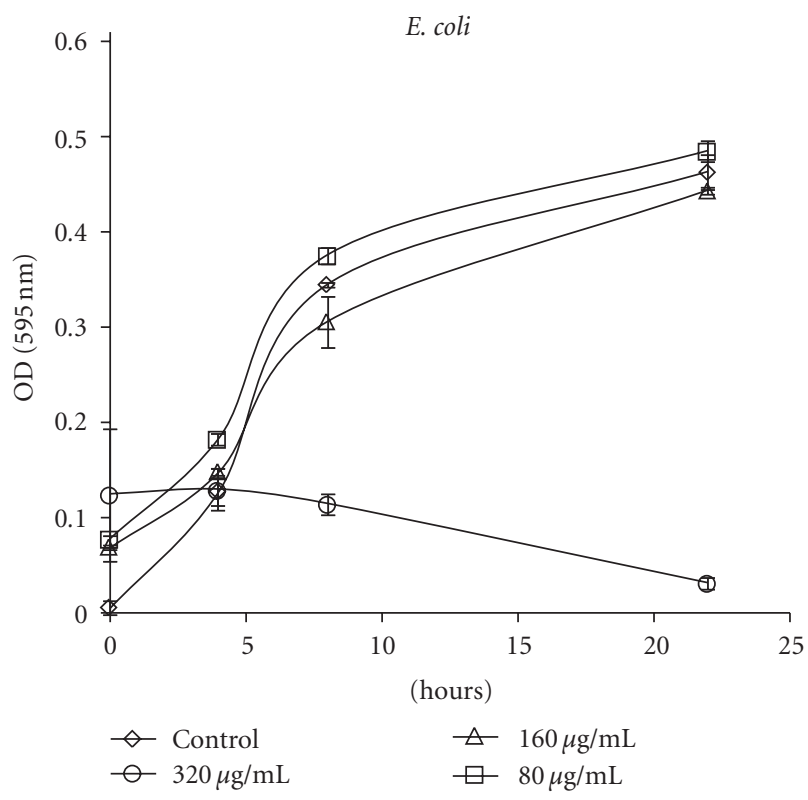

(b)

FIGURE 1: Kinetic measurements of bacterial outgrowth applying various concentrations of QA-PEI nanoparticles (i.e., no. I). The growth of the bacteria (a) S. aureus and (b) E. coli was measured every several hours during 24 hours. Each point on the curve is the average absorbance $\left(\mathrm{A}_{595}\right)$ measured simultaneously in three wells similarly prepared in the same microtiter plate.

TABLE 1: Characterization of QA-PEI nanoparticles at different degrees of alkylation prepared via reductive amination.

\begin{tabular}{|c|c|c|c|c|c|c|c|c|}
\hline \multirow{2}{*}{ Code } & \multirow{2}{*}{ Degree of alkylation ${ }^{a}$} & \multirow{2}{*}{ Inhibition concentration ${ }^{\mathrm{b}}$} & \multicolumn{3}{|c|}{ Elemental analysis $^{c}$} & \multirow{2}{*}{$\mathrm{C} / \mathrm{N}^{\mathrm{d}}$} & \multirow{2}{*}{ Particlesize $(\mathrm{nm})^{\mathrm{e}}$} & \multirow{2}{*}{ Zeta potential $(\mathrm{mV})^{\mathrm{f}}$} \\
\hline & & & $\% \mathrm{~N}$ & $\% \mathrm{C}$ & $\% \mathrm{I}$ & & & \\
\hline A & $1: 1$ & $40 \mu \mathrm{g} / \mathrm{mL}$ & 7.03 & 32.74 & 54.00 & 3.61 & $24 \pm 10$ & $85 \pm 10$ \\
\hline B & $1: 0.75$ & $40 \mu \mathrm{g} / \mathrm{mL}$ & 9.05 & 33.63 & 49.25 & 3.16 & $116 \pm 100$ & $60 \pm 31$ \\
\hline $\mathrm{C}$ & $1: 0.5$ & $80 \mu \mathrm{g} / \mathrm{mL}$ & 8.85 & 30.94 & 54.25 & 2.81 & $56 \pm 25$ & $72 \pm 31$ \\
\hline $\mathrm{D}$ & $1: 0.25$ & $160 \mu \mathrm{g} / \mathrm{mL}$ & 9.26 & 29.60 & 53.70 & 2.45 & $108 \pm 106$ & $80 \pm 47$ \\
\hline
\end{tabular}

Octanal was reacted with cross-linked PEI nanoparticles at various mole ratios via reductive amination followed by N-methylation under the same conditions as described in the experimental section.

a Mole ratio of reactants (primary amine of PEI monomer units/alkylating agent).

${ }^{b}$ Concentration of the tested compound used for a complete inhibition of $>10^{5} \mathrm{~S}$. aureus growth. ${ }^{\mathrm{c}}$ Found Nitrogen, Carbon, and Iodine content of QA-PEI (elemental analysis). ${ }^{\mathrm{d}} \mathrm{C} / \mathrm{N}$ was determined by elemental analysis of the alkylated samples before methylation step, whereas $\mathrm{C} / \mathrm{N}$ of the nonalkylated PEI was found to be 2.26. ${ }^{\mathrm{e}}$ Apparent particle size of QA-PEI nanoparticles (diameter). ${ }^{\mathrm{f}}$ Zeta potential of QA-PEI nanoparticles.

54.26, elemental analysis of I (\%) after exchange reaction: 18.31 .

\subsubsection{QA-PEI-Methoxypoly (Ethylene Glycol) (MPEG) Con-} jugation. Activation of MPEG with p-nitrophenyl chloroformate was obtained as described elsewhere [23]. PEI (10 g, $0.23 \mathrm{~mol}$ of monomer units) was dissolved in $100 \mathrm{~mL}$ of absolute ethanol. Dibromopentane was added at 1:0.04 mole ratio (monomer units of $\mathrm{PEI} /$ dibromopentane). Crosslinking reaction was carried out under reflux conditions for 24 hours. MPEG 2000 -p-nitrophenyl carbonate $(0.5 \%$ and $5 \% \mathrm{~mol} / \mathrm{mol}$ to $\varepsilon-\mathrm{NH}_{2}$ ) was added to the cross-linked PEI nanoparticles dispersion. The mixture was stirred under reflux conditions for 24 hours.
$\mathrm{N}$-alkylation was conducted as follows: octyl halide was added at $1: 1$ mole ratio (primary amine of PEI monomer units/octyl halide) to the same flask. Alkylation step was carried out under reflux conditions for 24 hours. Excess $\mathrm{NaHCO}_{3}$ (1.25 equimolar of octyl halide) was added to neutralize released acid. Neutralization reaction was continued from 3 to 24 hours at the same conditions.

$\mathrm{N}$-methylation was conducted as follows: methylation step was carried out with $43 \mathrm{~mL}$ of methyl iodide $(0.69 \mathrm{~mol})$ added at 1:3 mole ratio to the same flask (monomer units of $\mathrm{PEI} /$ methyl iodide). Methylation was continued at $42^{\circ} \mathrm{C}$ for 48 hours. An equivalent amount of sodium bicarbonate $(0.23 \mathrm{~mol}, 19 \mathrm{~g})$ was added to collect released HI during methylation step. Neutralization was continued at the same conditions for additional 24 hours. Formed NaI salt and 
TABLE 2: Characterization of QA- PEI nanoparticles prepared via reductive amination and N-alkylation.

\begin{tabular}{|c|c|c|c|c|c|c|c|c|c|}
\hline \multirow{2}{*}{ Code } & \multirow{2}{*}{ Degree of alkylation ${ }^{a}$} & \multirow{2}{*}{$\begin{array}{l}\text { Inhibition } \\
\text { concentration }^{\mathrm{b}}\end{array}$} & \multicolumn{3}{|c|}{ Elemental analysis $^{\mathrm{c}}$} & \multirow{2}{*}{$\mathrm{C} / \mathrm{N}^{\mathrm{d}}$} & \multirow{2}{*}{$\begin{array}{l}\text { Particlesize } \\
(\mathrm{nm})^{\mathrm{e}}\end{array}$} & \multirow{2}{*}{$\begin{array}{l}\text { Zeta } \\
\text { potential }(\mathrm{mV})^{\mathrm{f}}\end{array}$} & \multirow{2}{*}{ Primary amine } \\
\hline & & & $\% \mathrm{~N}$ & $\% \mathrm{C}$ & $\% \mathrm{I}$ & & & & \\
\hline A & $1: 1$ & $80 \mu \mathrm{g} / \mathrm{mL}$ & 7.03 & 32.74 & 54.00 & 3.61 & $24 \pm 10$ & $85 \pm 10$ & $3.21 * 10^{-4}$ \\
\hline I & $1: 1$ & $80 \mu \mathrm{g} / \mathrm{mL}$ & 7.24 & 35.38 & 43.16 & 3.56 & $40 \pm 18$ & $63 \pm 27$ & $3.37 * 10^{-4}$ \\
\hline
\end{tabular}

a,c-f See notes in Table 1.

${ }^{b}$ Concentration of the tested compound needed for a complete inhibition of $>10^{6} \mathrm{~S}$. aureus growth.

g Amount of primary amine ( $\mathrm{mmol} / \mathrm{g})$ in conjugates determined by the TNBS method following alkylation step, while prior alkylation primary amine of PEI was $5.8 \mathrm{mmol} / \mathrm{g}$.

TABLE 3: Characterization of PEI-based nanoparticles at different degrees of N-methylation.

\begin{tabular}{|c|c|c|c|c|c|c|c|}
\hline \multirow{2}{*}{ Code } & \multirow{2}{*}{ Inhibition concentration $^{a}$} & \multicolumn{3}{|c|}{ Elemental analysis $^{\mathrm{b}}$} & \multirow{2}{*}{$\mathrm{C} / \mathrm{N}^{\mathrm{c}}$} & \multirow{2}{*}{ Particle size $(\mathrm{nm})^{\mathrm{d}}$} & \multirow{2}{*}{ Zeta potential $(\mathrm{mV})^{\mathrm{e}}$} \\
\hline & & $\% \mathrm{~N}$ & $\% \mathrm{C}$ & $\% \mathrm{I}$ & & & \\
\hline $\mathrm{F} 1$ & $\mathrm{NA}^{*}$ & 6.52 & 29.90 & 51.12 & 3.86 & $36 \pm 28$ & $79 \pm 25$ \\
\hline $\mathrm{F} 2$ & $\mathrm{NA}^{*}$ & 6.06 & 28.13 & 52.60 & 3.86 & $20 \pm 20$ & $79 \pm 38$ \\
\hline F3 & $80 \mu \mathrm{g} / \mathrm{mL}$ & 7.22 & 36.39 & 46.62 & 3.86 & $34 \pm 29$ & $97 \pm 20$ \\
\hline
\end{tabular}

Cross-linked PEI nanoparticles were reacted with octyl halide at 1:1 mole ratio (primary amine of PEI/alkylating agent) followed by N-methylation with various equivalents of methyl iodide, under the same conditions as described in experimental section.

* Not active at $80 \mu \mathrm{g} / \mathrm{mL}$ or below.

${ }^{a}$ Concentration of the tested compound used for a complete inhibition of $>10^{6}$ S. aureus growth. ${ }^{b}$ Found Nitrogen, Carbon, and Iodine content of QA-PEI (elemental analysis). ${ }^{\mathrm{c}} \mathrm{C} / \mathrm{N}$ was determined by elemental analysis of the alkylated samples before methylation step whereas $\mathrm{C} / \mathrm{N}$ of the nonalkylated PEI was found to be 2.26 .

${ }^{\mathrm{d}}$ Apparent particle size of QA-PEI nanoparticles (diameter). ${ }^{\mathrm{e}}$ Zeta potential of QA-PEI nanoparticles.

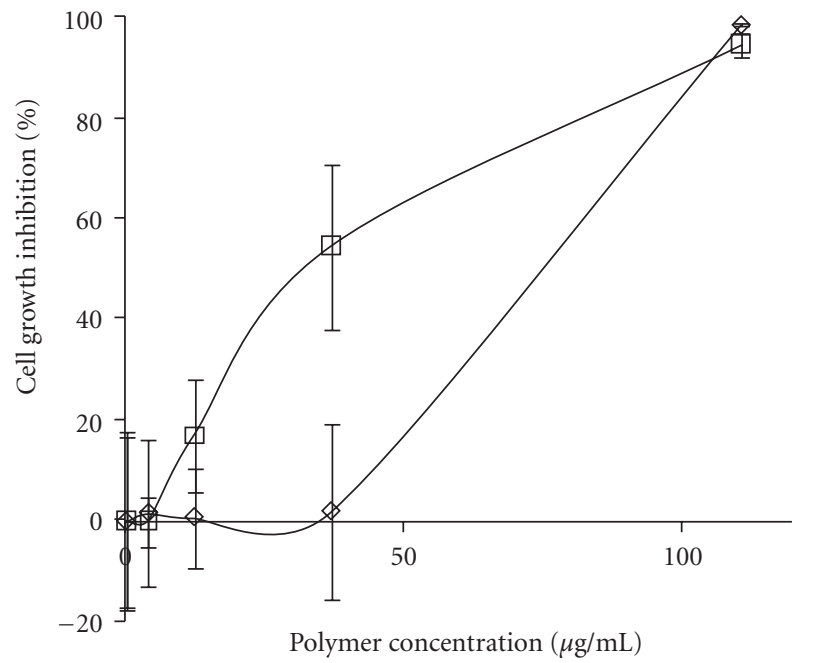

$$
\begin{aligned}
& \diamond \text { MAT-LYLU } \\
& \square \text { MBT }
\end{aligned}
$$

FIGURE 2: Evaluation of cytotoxicity of QA-PEI nanoparticles (i.e., no. I) (determined by cell growth inhibition). The cytotoxicity test was performed by the $\left[{ }^{3} \mathrm{H}\right]$-thymidine incorporation method using MBT and MAT-LyLu cells which were incubated with various concentrations of QA-PEI. Each experiment was performed in triplicate.

excess of unreacted $\mathrm{NaHCO}_{3}$ were discarded by decantation, and the residue was precipitated in $300 \mathrm{~mL}$ of DDW, washed with hexane and DDW to remove traces of the unreacted octyl halide, methyl iodide, unreacted MPEG, released pnitrophenol, and inorganic salts, respectively, and freezedried. The purification step was repeated with additional amounts of hexane and DDW, and the product was freezedried. Average yield: 49\% ( $\mathrm{mol} / \mathrm{mol})$.

The degree of PEGylation was found to be about $90 \%$ $(\sim$ to starting feed) as determined by spectrophotometric measurement of the released p-nitrophenol (UV, $\lambda=410 \mathrm{~nm}$ ) [23].

${ }^{1} \mathrm{H}-\mathrm{NMR}$ (PEG-QA-PEI nanoparticles, DMSO- $\left.\mathrm{d}_{6}\right)$ : $0.853 \mathrm{ppm}$ ( $\mathrm{t}, 3 \mathrm{H}, \mathrm{CH}_{3}$, octyl protons), $1.245 \mathrm{ppm}(\mathrm{m}$, $10 \mathrm{H},-\mathrm{CH}_{2}-$, octyl protons), $1.7 \mathrm{ppm}\left(\mathrm{m}, 2 \mathrm{H},-\mathrm{CH}_{2}-\right.$, octyl protons), 3.0-3.4 ppm ( $\mathrm{m},-\mathrm{CH}_{2}-$, MPEG protons), $3.4-4.0 \mathrm{ppm}$ ( $\mathrm{m}$, methyl of quaternary amine, $4 \mathrm{H}$ of PEI and $2 \mathrm{H}$ of the octyl chain), and $4.2 \mathrm{ppm}(\mathrm{m}, 2 \mathrm{H}$, $\left.\mathrm{CH}_{3}\left(\mathrm{OCH}_{2} \mathrm{CH}_{2}\right)_{n} \mathrm{OCH}_{2} \mathrm{CH}_{2} \mathrm{OCONH}-\right)$.

2.2.6. Antibacterial Activity of Quaternary Ammonium Polyethyleneimine (QA-PEI) Nanoparticles. Bacterial suspensions of $S$. aureus and $E$. coli were prepared by dilution in tryptic soy broth (TSB) and lambda broth (LB), respectively. The suspension was adjusted to an optical density of 0.15 at $595 \mathrm{~nm}$. Working suspensions were then prepared by further dilution with the appropriate medium in order to reach $10^{6}$ colony-forming units (CFU/250 $\mu \mathrm{L} /$ well within 96-well flat bottom plate) of bacteria. The microtiter plate was incubated at $37^{\circ} \mathrm{C}$ for 24 hours. During the incubation period, bacterial growth was estimated by following the changes in optical density (OD) measured at $595 \mathrm{~nm}$ using a spectrophotometer (VERSAmax, Molecular Devices Corporation, CA, USA). The minimal inhibitory concentration (MIC) of the tested compound was defined as the lowest concentration that 

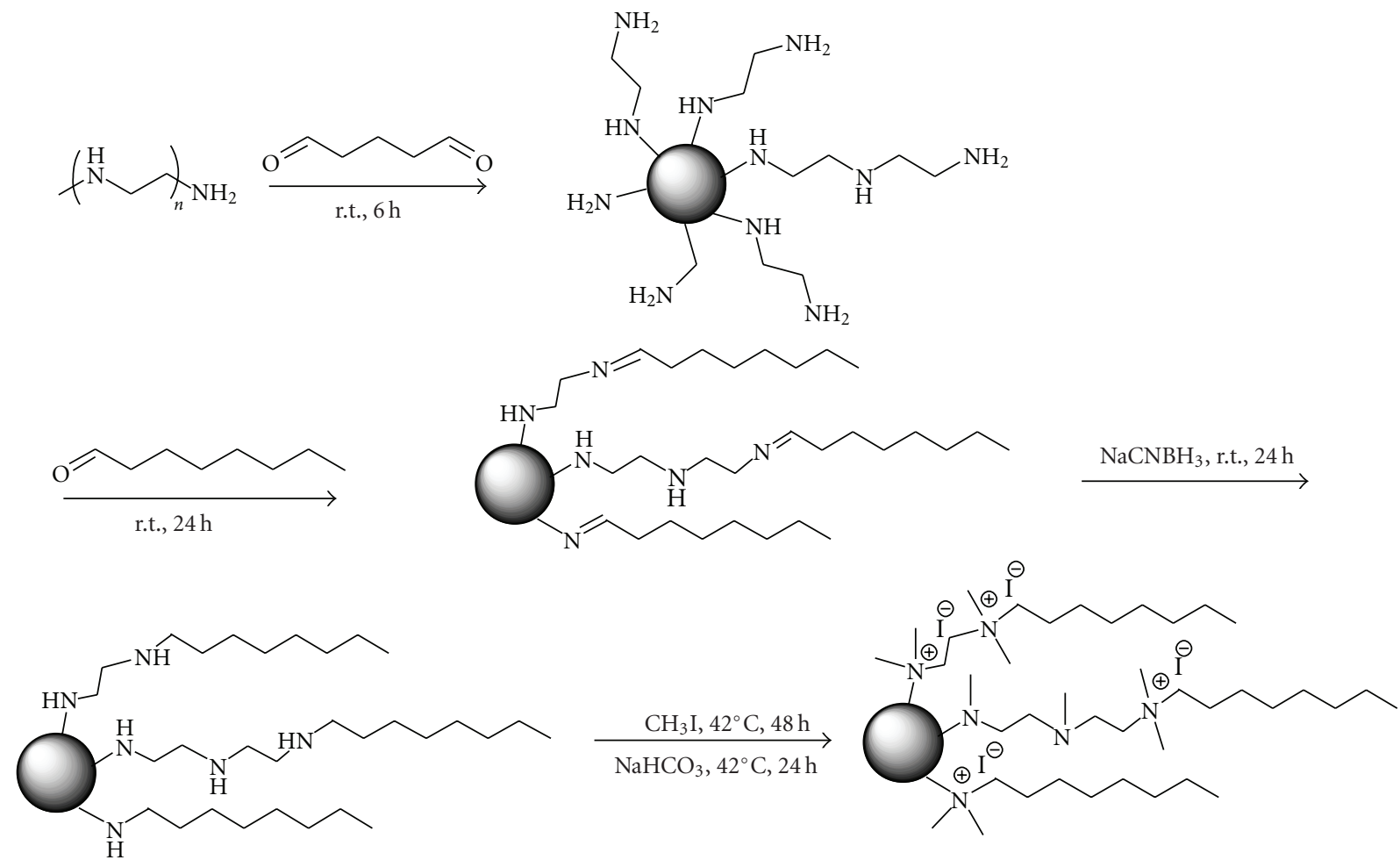

(a) Reductive amination method (\#A)

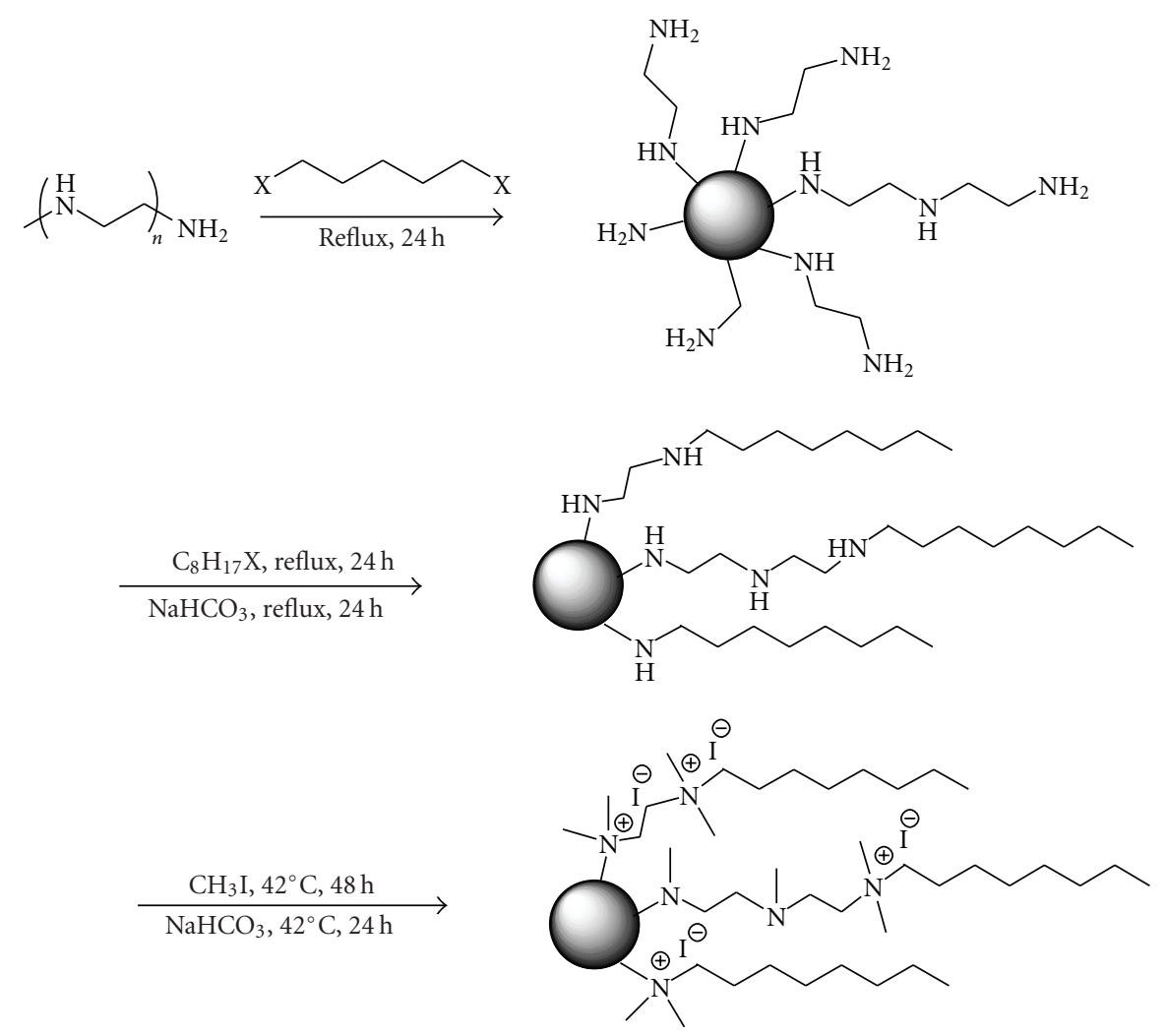

(b) N-alkylation method (\#I)

Scheme 1: Continued. 


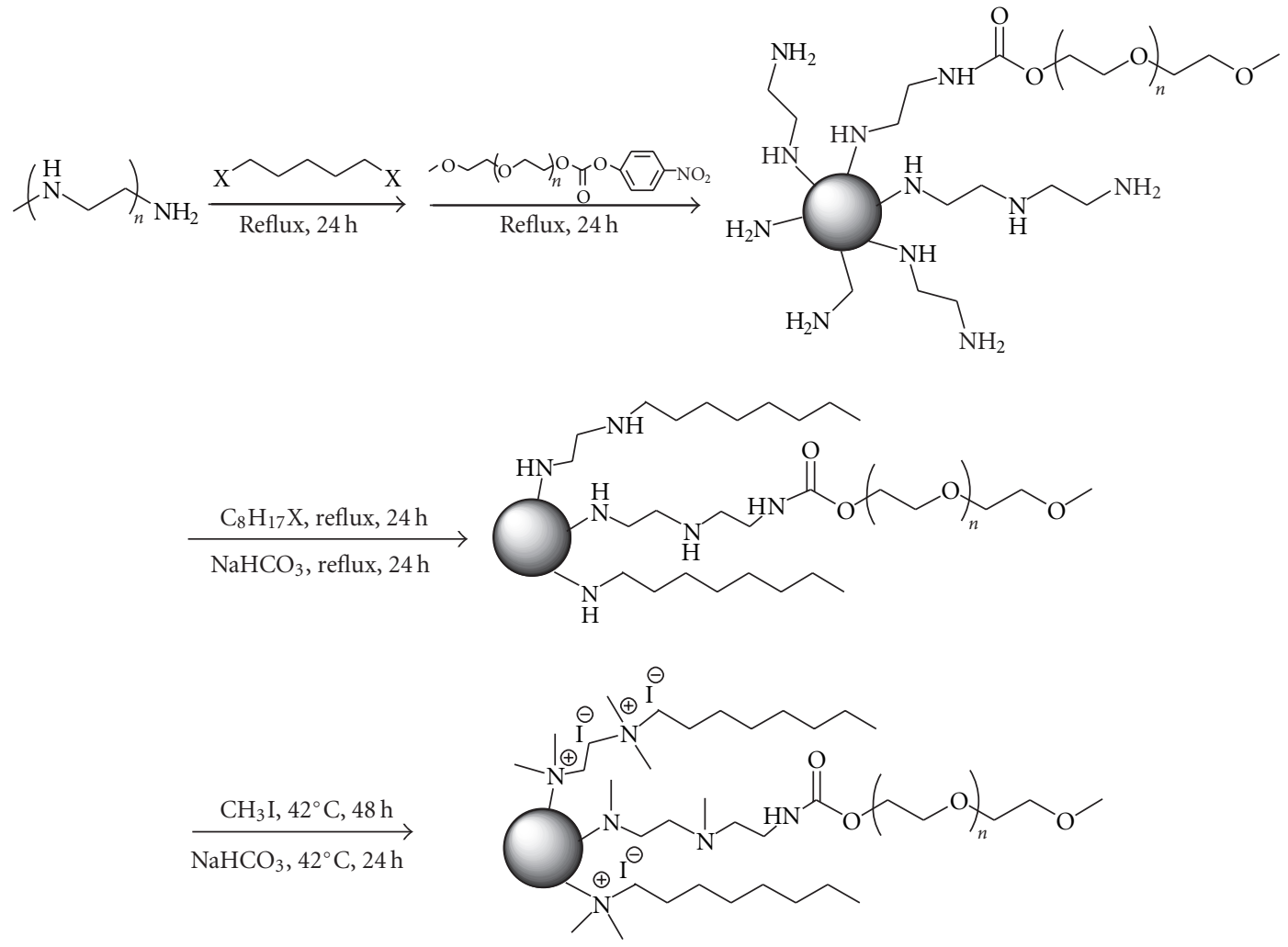

(c) Modification with methoxypoly (ethylene glycol) (\#E)

SCHEME 1: Synthesis of quaternary ammonium polyethyleneimine nanoparticles.

completely inhibits bacterial growth compared to the QAPEI-free growth control. All the experiments were performed in triplicate and the mean values were calculated.

\subsubsection{In Vitro Toxicity of Quaternary Ammonium Polyethyl-} eneimine (QA-PEI) Nanoparticles. Serial dilutions of QAPEI were prepared in RPMI 1640 growth medium. The cytotoxicity of QA-PEI was evaluated in Murine Bladder Tumor (MBT) and MAT-LYLU cells. Growth inhibition was estimated by $\left[{ }^{3} \mathrm{H}\right]$-thymidine incorporation method. Cells were cultured in flat-bottom flasks at $37^{\circ} \mathrm{C}$. Before each experiment, the cells were washed and removed by trypsin treatment or scraped from the flask bottom, and an appropriate volume was centrifuged, resuspended, and diluted in growth medium to the desired cell concentration (4000 cells/200 $\mu \mathrm{l}$ ). The growth medium consisted of RPMI 1640 and 10\% fetal calf serum (FCS). By use of an automated dispenser, $200 \mu \mathrm{L}$ of cell suspension was added to each well of a microtiter plate. After incubation overnight, the appropriate QA-PEI concentration, in triplicate, was added to test wells. QA-PEI-free medium was used as control. $\left[{ }^{3} \mathrm{H}\right]$-Thymidine $(0.5 \mu \mathrm{Ci})$ in $20 \mu \mathrm{L}$ of medium was added the next day, and the plate was harvested and read by liquid scintillation counter (LKB, Finland) after additional 24 hours. The percent growth inhibition of the cells by QA-PEI nanoparticles was calculated as [100-(count with
QA-PEI/control count $) \times 100]$. The effective dose $50\left(\mathrm{ED}_{50}\right)$ is calculated as QA-PEI concentration that reduces $\left[{ }^{3} \mathrm{H}\right]$ thymidine incorporation by $50 \%$, relative to the control.

\section{Results and Discussion}

Quaternary ammonium polyethyleneimine (QA-PEI) nanoparticles were prepared using two synthetic methods, that is, reductive amination and $\mathrm{N}$-alkylation. According to the first method, QA-PEI nanoparticles were synthesized by crosslinking of polyethyleneimine with glutaraldehyde followed by reductive amination with octanal and further $\mathrm{N}$ methylation with methyl iodide as illustrated in Scheme 1(a). The second method is based on crosslinking with dibromopentane followed by $\mathrm{N}$-alkylation with octyl halide and further $\mathrm{N}$-methylation with methyl iodide resulting in nanoparticles of spherical shape [20] (Scheme 1(b)).

The most effective QA-PEI derivative was QA-PEI alkylated with octyl halide at $1: 1$ mole ratio (primary amine of PEI monomer units/alkylating agent), which inhibited $>10^{6}$ S. aureus growth at a concentration of $80 \mu \mathrm{g} / \mathrm{mL}$.

There was a strict correlation between the activity of the compounds and their overall octyl content. Although several structural parameters influenced the antibacterial potency of the QA-PEI nanoparticles, the most important features appear to be the degree of alkylation and degree of 
TABLE 4: Characterization of QA-PEI nanoparticles with different counter anions.

\begin{tabular}{|c|c|c|c|c|c|c|}
\hline Code & Counter ion & Inhibition concentration $^{\mathrm{a}}$ & Elemental analysisof (\%) $\mathrm{I}^{\mathrm{b}}$ & $\mathrm{C} / \mathrm{N}^{c}$ & Particle size $(\mathrm{nm})^{\mathrm{d}}$ & Zeta potential $(\mathrm{mV})^{\mathrm{e}}$ \\
\hline G & Nitrate & $40 \mu \mathrm{g} / \mathrm{mL}$ & 4.65 & 3.64 & $96 \pm 80$ & $64 \pm 59$ \\
\hline $\mathrm{H}$ & Acetate & $40 \mu \mathrm{g} / \mathrm{mL}$ & 18.31 & 3.64 & $154 \pm 100$ & $105 \pm 30$ \\
\hline I & Iodide & $80 \mu \mathrm{g} / \mathrm{mL}$ & 43.16 & 3.56 & $40 \pm 18$ & $63 \pm 27$ \\
\hline
\end{tabular}

a-e See notes in Table 3.

TABLE 5: Characterization of QA-PEI nanoparticles with different degrees of PEGYlation.

\begin{tabular}{|c|c|c|c|c|c|c|c|c|}
\hline \multirow{2}{*}{ Code } & \multirow{2}{*}{ Degree of PEGylation } & \multirow{2}{*}{ Inhibition concentration $^{a}$} & \multicolumn{3}{|c|}{ Elemental analysis $^{\mathrm{b}}$} & \multirow{2}{*}{$\mathrm{C} / \mathrm{N}^{\mathrm{c}}$} & \multirow{2}{*}{ Particle size $(\mathrm{nm})^{\mathrm{d}}$} & \multirow{2}{*}{ Zeta potential $(\mathrm{mV})^{c}$} \\
\hline & & & $\% \mathrm{~N}$ & $\% \mathrm{C}$ & $\% \mathrm{I}$ & & & \\
\hline I & $0 \%$ & $80 \mu \mathrm{g} / \mathrm{mL}$ & 7.24 & 35.38 & 43.16 & 3.56 & $40 \pm 18$ & $63 \pm 27$ \\
\hline $\mathrm{J}$ & $0.5 \%$ & $40 \mu \mathrm{g} / \mathrm{mL}$ & 7.03 & 32.74 & 54.00 & 3.79 & $24 \pm 15$ & $85 \pm 10$ \\
\hline E & $5 \%$ & $40 \mu \mathrm{g} / \mathrm{mL}$ & 8.85 & 30.94 & 54.25 & 3.84 & $56 \pm 50$ & $73 \pm 31$ \\
\hline
\end{tabular}

${ }^{a-e}$ See notes in Table 3.

methylation, while other parameters played a less significant role.

\subsection{Determination of Minimal Inhibitory Concentration of} QA-PEI Nanoparticles. The goal of this study was to evaluate antibacterial properties of QA-PEI against Gram-negative and Gram-positive bacteria including E. coli and S. aureus, respectively. Bacteria were exposed to various concentrations $(40-320 \mu \mathrm{g} / \mathrm{mL})$ of the QA-PEI for 24 hours at $37^{\circ} \mathrm{C}$. Figure 1 summarizes the change in the bacterial growth after applying QA-PEI nanoparticles. A culture containing bacteria without nanoparticles was used as a negative control. Antibacterial analysis indicated that QA-PEI completely inhibited $S$. aureus and E. coli growth at $80 \mu \mathrm{g} / \mathrm{mL}$ (Figure 1(a)) and at $320 \mu \mathrm{g} / \mathrm{mL}$ (Figure $1(\mathrm{~b})$ ), respectively.

\subsection{Effect of the Alkylation Degree on Antibacterial Activity.} QA-PEI nanoparticles were prepared via reductive amination method followed by further N-methylation, which raises their positive charge by converting PEI's primary, secondary, and tertiary amino groups into cationic quaternary amino groups. Cross-linked PEI nanoparticles were allowed to react under similar conditions with increasing amounts of octanal ranging from $1: 0.25$ to $1: 1$ mole ratios (primary amine of PEI monomer units/octanal). The resulting imine conjugates were reduced to amine bonds by sodium cyanoborohydride. Table 1 summarizes the chemical data obtained with QAPEI substituted with various degrees of octanal. Increased amount of octanal resulted in more hydrophobized compound which was evidenced by elevated carbon/nitrogen $(\mathrm{C} / \mathrm{N})$ ratio. For instance, QA-PEI nanoparticles alkylated at $1: 1$ mole ratio (primary amine of PEI monomer units/octanal), no. A, resulted in $\mathrm{C} / \mathrm{N}$ of 3.61 in comparison with $\mathrm{C} / \mathrm{N}$ of 2.45 obtained with QA-PEI alkylated at $1: 0.25$ mole ratio, no. D. According to the antibacterial assay, the alkylation degree was in correlation with the bactericidal activity of the QA-PEI (Table 1). In particular, QA-PEI nanoparticles alkylated at 1:1 mole ratio (primary amine of PEI monomer units/octanal) (no. A), and even lower, for example, 1:0.75 mole ratio (no. B) were most effective in $S$. aureus growth inhibition, while a compound with very low degree of alkylation ( $1: 0.25$ mole ratio, no. D) depicted reduced antibacterial activity. Thus, the degree of alkylation had a decisive influence on the antibacterial properties of the nanoparticles as evidenced by reduced antibacterial activity of the QA-PEI modified with low degree of alkylation. We surmise that this inactivity of the less substituted QA-PEI is probably attributed to insufficient hydrophobic nature of the nanoparticles. Increased hydrophobicity, achieved due to increased alkylation degree, might enhance QAPEI nanoparticles propensity to penetrate the hydrophobic bacterial membrane which is expressed in enhanced antibacterial properties. Indeed, Lin et al. reported on antibacterial activity of the alkylated PEI coatings for glass slide, suggesting that bactericidal surfaces with immobilized long polymeric chains have to be hydrophobic to be highly effective in bacterial removal [16]. On the basis of these results, 1:1 mole ratio (primary amine of PEI monomer units/alkylating agent) was used as optimal mole ratio for QA-PEI synthesis.

\subsection{Comparison of QA-PEI Antibacterial Activity Prepared} via Different Synthetic Methods. The purpose of this issue is to evaluate the relationship between the biological activity and the chemical characterization of QA-PEI nanoparticles prepared via two different synthetic methods, that is, reductive amination and $\mathrm{N}$-alkylation. According to the chemical analysis (Table 2), QA-PEI nanoparticles prepared via two methods exhibit similar nitrogen $(\% \mathrm{~N})$, carbon $(\% \mathrm{C})$, and iodine $(\% \mathrm{I})$ content, apparent particle size (ALV, nm), zeta potential, and primary amine content determined following alkylation step. Although reductive amination and $\mathrm{N}$-alkylation methods resulted in QA-PEI nanoparticles bearing different particle sizes and zeta potential, no distinct difference in antibacterial activity was observed applying both types of QA-PEI nanoparticles. Based on these results the N-alkylation method was selected for further studies, due to its simplicity in synthesis, work up, and use of nonexpensive reagents. 
TABLE 6: Characterization of QA-PEI nanoparticles.

\begin{tabular}{|c|c|c|c|c|c|c|}
\hline \multirow{2}{*}{ Code } & \multicolumn{3}{|c|}{ Elemental analysis $^{\mathrm{a}}$} & \multirow{2}{*}{$\mathrm{C} / \mathrm{N}^{\mathrm{b}}$} & \multirow{2}{*}{ Particle size $(\mathrm{nm})^{\mathrm{c}}$} & \multirow{2}{*}{ Zeta potential $(\mathrm{mV})^{\mathrm{d}}$} \\
\hline & $\% \mathrm{~N}$ & $\% \mathrm{C}$ & $\% \mathrm{I}$ & & & \\
\hline I & 7.24 & 35.38 & 43.16 & 3.56 & $40 \pm 18$ & $63 \pm 27$ \\
\hline K & 7.31 & 36.45 & 43.00 & 3.69 & $42 \pm 20$ & $69 \pm 16$ \\
\hline $\mathrm{L}$ & 6.87 & 35.31 & 43.36 & 3.64 & $40 \pm 19$ & $74 \pm 35$ \\
\hline M & 7.22 & 36.39 & 46.62 & 3.86 & $34 \pm 30$ & $97 \pm 20$ \\
\hline $\mathrm{N}$ & 7.39 & 35.16 & 45.72 & 3.60 & $16 \pm 12$ & $51 \pm 6$ \\
\hline $\mathrm{P}$ & 6.60 & 34.31 & 49.98 & 3.65 & $12 \pm 10$ & $82 \pm 40$ \\
\hline $\mathrm{O}$ & 7.07 & 34.43 & 48.71 & 3.71 & $16 \pm 12$ & $70 \pm 43$ \\
\hline $\mathrm{Q}$ & 6.87 & 34.63 & 47.87 & 3.68 & $16 \pm 5$ & $79 \pm 15$ \\
\hline
\end{tabular}

${ }^{a-e}$ See notes in Table 3.

3.4. N-Methylation Effect on Antibacterial Activity. The purpose of this part of the study was to evaluate the $\mathrm{N}$ methylation effect and its influence on the antibacterial activity of QA-PEI nanoparticles. Lin et al. have already shown that $\mathrm{N}$-methylation of $\mathrm{N}$-alkylated immobilized PEI enhanced its overall antibacterial activity [16]. Therefore, we tested the antibacterial properties of QA-PEI as a function of added equivalents of methyl iodide. QA-PEI nanoparticles were similarly prepared starting from crosslinked PEI nanoparticles and octyl halide added at 1:1 mole ratio (primary amine of PEI monomer units/octyl halide). Different equivalents of methyl iodide ranging from $1: 1$ to $1: 3$ mole ratios (monomer units of $\mathrm{PEI} /$ methyl iodide) were used during the methylation step. Table 3 summarizes the chemical characterization of QA-PEI nanoparticles, including nitrogen $(\% \mathrm{~N})$, carbon $(\% \mathrm{C})$, and iodine $(\% \mathrm{I})$ content determined prior to the neutralization step, apparent particle size $(\mathrm{ALV}, \mathrm{nm})$, zeta potential and structure (FT-IR and ${ }^{1} \mathrm{H}-\mathrm{NMR}$ are shown in Experimental Section). S. aureus was incubated with various concentrations $(0-80 \mu \mathrm{g} / \mathrm{mL})$ of QA-PEI for 24 hours. As seen in the Table 3, when 1 or 2 equivalents of methyl iodide were used (e.g., no. F1 and no. F2, resp.), no bacterial inhibition was observed with QAPEI up to $80 \mu \mathrm{g} / \mathrm{mL}$ suggesting an insufficient $\mathrm{N}$-methylation degree. However, 3 equivalents of methyl iodide yielded highly effective QA-PEI nanoparticles which abolished $S$. aureus growth at $80 \mu \mathrm{g} / \mathrm{mL}$ (e.g., no. F3). Thus, methylation following initial alkylation elevates bactericidal efficiency of the QA-PEI nanoparticles.

3.5. Antibacterial Activity of QA-PEI Nanoparticles as a Function of Counter Ion. To examine the effect of counter ion on bacterial growth, QA-PEI nanoparticles with various counter ions were applied. For this reason iodide counter anion of QA-PEI nanoparticles was exchanged with nitrate ion using precipitation method with $\mathrm{AgNO}_{3}$ and with acetate using $1 \mathrm{~N}$ acetic acid solution. QA-PEI nanoparticles were characterized prior and following exchange reaction for their iodine (\%I) content, apparent particle size (ALV, nm), and zeta potential as shown in Table 4. S. aureus was incubated with various concentrations $(0-80 \mu \mathrm{g} / \mathrm{mL})$ of QA-PEI for 24 hours. Although iodide counter ion was partly substituted with nitrate and acetate anions, antibacterial analysis revealed that QA-PEI iodide, nitrate, and acetate form nanoparticles demonstrated similar efficiency in bacterial growth inhibition, indicating a minor effect on antibacterial activity. Previous studies have shown similar results, for example, Chen et al. revealed that counter ions including chloride and bromide showed no effect on the antibacterial activity of the quaternary ammonium biocides [24]. In addition, Panarin et al. reported on analogous findings obtained with various counter ions for quaternary ammonium groups of homopolymers based on vinylamine and methyl methacrylate [25]. However, Kanazawa et al. found that antibacterial properties of the poly(tributyl 4-vinyl benzyl phosphonium halide) were in the order of chloride $>$ boron tetrafluoride $>$ perchlorate $>$ hexafluorophosphate indicating a counter ion dependence. Counter ion effect is widely an argued point; there is still no clear answer why counter ion should affect antibacterial properties except where it alters the solubility of the biocides [20, 26-28].

3.6. PEGylation Effect. The purpose of this part of the study was to evaluate the wettability effect of methoxypoly(ethylene glycol) (MPEG) and its influence on antibacterial activity of QA-PEI. Previous studies have shown that hydrophilic coating may increase the surface energy of the material due to enhanced hydrophilicity following PEGylation and consequently increase bacterial interaction with the bactericide surface. For instance, Sellenet et al. have reported on quaternerized polyvinyl pyridine incorporated with hydroxyethyl methacrylate and poly(ethylene glycol) methyl ether methacrylate that elevated antibacterial activity 20 times greater than the pure quaternerized poly(vinyl pyridine) [29]. For this reason QA-PEI was modified with increasing amounts of MPEG (Scheme 1(c)). MPEG $\left(\mathrm{M}_{\mathrm{w}}=\right.$ $2 \mathrm{kDa}$ ) was activated with p-nitrophenyl chloroformate to obtain p-nitrophenyl carbonate derivative. Substitution of QA-PEI was carried out at reflux conditions in ethanol as described in Experimental Section. The amount of MPEG was fixed at $0.5 \%$ and $5 \%(\mathrm{~mol} / \mathrm{mol})$ to primary amines of polyethyleneimine. QA-PEI nanoparticles were characterized for their nitrogen $(\% \mathrm{~N})$, carbon $(\% \mathrm{C})$, and iodine $(\% \mathrm{I})$ content, apparent particle size (ALV, nm), and zeta potential as shown in Table 5. S. aureus was incubated with various concentrations $(80-320 \mu \mathrm{g} / \mathrm{mL})$ of pegylated QA-PEI for 
24 hours. No significant difference was observed in the antibacterial activity of MPEG derivatives (e.g., no. J and no. E) in comparison with unPEGylated QA-PEI (e.g., no. I). These findings indicate that MPEG modification did not significantly improve the bactericidal efficiency of the QA-PEI nanoparticles, suggesting a moderate effect on interaction between bacterial membrane and pegylated QAPEI nanoparticles.

3.7. Cytotoxicity Evaluation of QA-PEI Nanoparticles. An important issue for the usefulness of antibacterial QA-PEI nanoparticles is whether these nanoparticles are harmful to mammalian cells. Lethal activity against bacteria with minimal effect on cell viability is required for clinical applications such as medical devices with antimicrobial properties. $\left[{ }^{3} \mathrm{H}\right]$-thymidine incorporation is a well-known technique for testing cell proliferation. QA-PEI nanoparticles (i.e., no. I) which toxicity might be attributed to strong positive charge of the nanoparticles, were incubated with MAT-LuLy and MBT cell lines for 48 hours. The results presented in Figure 2 lead to several conclusions. First, no effect on MAT-LyLu cultures was observed using up to $37 \mu \mathrm{g} / \mathrm{mL}$ of QA-PEI. The calculated $\mathrm{ED}_{50}$ was $75 \mu \mathrm{g} / \mathrm{mL}$. Second, exposure of MBT cultures to QA-PEI resulted in $\mathrm{ED}_{50}$ of $30 \mu \mathrm{g} / \mathrm{mL}$. Thymidine incorporation was completely abolished in both cultures after exposure to $111 \mu \mathrm{g} / \mathrm{mL}$ of QA-PEI nanoparticles. The inhibitory effect of QA-PEI on the proliferation of the MAT-LYLU cells was in a much lesser extent than on MBT cell line.

3.8. Reproducibility. In a typical experiment, 8 QA-PEI samples were prepared in different batches starting from cross-linked PEI nanoparticles and octyl halide added at $1: 1$ mole ratio (primary amine of PEI monomer units/octyl halide) followed by methylation step. The purpose of this experiment was to evaluate the reproducibility of the synthesis and antibacterial activities of the various batches. Table 6 summarizes chemical analysis of these compounds.

According to the elemental analysis, averages of $\% \mathrm{~N}, \% \mathrm{C}$, and $\% \mathrm{I}$ in these batches were $7.07 \pm 0.47,35.25 \pm 1.2$, and $46.05 \pm 3.9$, respectively. The apparent particle size and zeta potential of these nanoparticles were $25 \mathrm{~nm} \pm 15 \mathrm{~nm}$ and $72.98 \mathrm{mV} \pm 23.9 \mathrm{mV}$, respectively. The antibacterial effect of these QA-PEI nanoparticles was evaluated against S. aureus, and the average inhibition concentration was $80 \mu \mathrm{g} / \mathrm{mL}$ indicating good reproducibility in antibacterial activity.

\section{Conclusion}

A series of cross-linked quaternary ammonium polyethyleneimine- (QA-PEI-) based nanoparticles were prepared using two synthetic methods including reductive amination between cross-linked PEI and octanal and N-alkylation with octyl halide followed by $\mathrm{N}$-methylation with methyl iodide. Although the majority of the tested compounds were found to be effective in inhibition of bacterial growth, QA-PEI nanoparticles alkylated at 1:1 mole ratio (primary amine of PEI monomer units/alkylating agent) showed the highest antibacterial activity. This work emphasizes that the structure of the polycationic nanoparticles has a significant role in the antibacterial activity. The presented results suggest that QA-PEI nanoparticles might be used as antibacterial additives for biomedical devices.

\section{References}

[1] T. Tashiro, "Antibacterial and bacterium adsorbing macromolecules," Macromolecular Materials and Engineering, vol. 286, no. 2, pp. 63-87, 2001.

[2] N. Kawabata and M. Nishiguchi, "Antibacterial activity of soluble pyridinium-type polymers," Applied and Environmental Microbiology, vol. 54, no. 10, pp. 2532-2535, 1988.

[3] E.-R. Kenawy, "Biologically active polymers. IV. Synthesis and antimicrobial activity of polymers containing 8hydroxyquinoline moiety," Journal of Applied Polymer Science, vol. 82, no. 6, pp. 1364-1374, 2001.

[4] I. Cakmak, Z. Ulukanli, M. Tuzcu, S. Karabuga, and K. Genctav, "Synthesis and characterization of novel antimicrobial cationic polyelectrolytes," European Polymer Journal, vol. 40, no. 10, pp. 2373-2379, 2004.

[5] J.-H. Jeong, Y.-S. Byoun, and Y.-S. Lee, "Poly(styrene-altmaleic anhydride)-4-aminophenol conjugate: synthesis and antibacterial activity," Reactive and Functional Polymers, vol. 50, no. 3, pp. 257-263, 2002.

[6] E.-R. Kenawy, F. I. Abdel-Hay, A. E.-R. R. El-Shanshoury, and M. H. El-Newehy, "Biologically active polymers: synthesis and antimicrobial activity of modified glycidyl methacrylate polymers having a quaternary ammonium and phosphonium groups," Journal of Controlled Release, vol. 50, no. 1-3, pp. 145152, 1998.

[7] R. Kügler, O. Bouloussa, and F. Rondelez, "Evidence of a charge-density threshold for optimum efficiency of biocidal cationic surfaces," Microbiology, vol. 151, no. 5, pp. 1341-1348, 2005.

[8] T. Nonaka, E. Noda, and S. Kurihara, "Graft copolymerization of vinyl monomers bearing positive charges or episulfide groups onto loofah fibers and their antibacterial activity," Journal of Applied Polymer Science, vol. 77, no. 5, pp. 10771086, 2000.

[9] A. J. Isquith, E. A. Abbott, and P. A. Walters, "Surfacebonded antimicrobial activity of an organosilicon quaternary ammonium chloride," Applied Microbiology, vol. 24, no. 6, pp. 859-863, 1972.

[10] G. Li and J. Shen, "A study of pyridinium-type functional polymers. IV. Behavioral features of the antibacterial activity of insoluble pyridinium-type polymers," Journal of Applied Polymer Science, vol. 78, no. 3, pp. 676-684, 2000.

[11] G. Li, J. Shen, and Y. Zhu, "A study of pyridinium-type functional polymers. III. Preparation and characterization of insoluble pyridinium-type polymers," Journal of Applied Polymer Science, vol. 78, no. 3, pp. 668-675, 2000.

[12] T. Ikeda, H. Yamaguchi, and S. Tazuke, "Phase separation in phospholipid bilayers induced by biologically active polycations," Biochimica et Biophysica Acta, vol. 1026, no. 1, pp. 105112, 1990.

[13] J. C. Tiller, S. B. Lee, K. Lewis, and A. M. Klibanov, "Polymer surfaces derivatized with poly(vinyl-N-hexylpyridinium) kill airborne and waterborne bacteria," Biotechnology and Bioengineering, vol. 79, no. 4, pp. 465-471, 2002.

[14] J. C. Tiller, C.-J. Liao, K. Lewis, and A. M. Klibanov, "Designing surfaces that kill bacteria on contact," Proceedings 
of the National Academy of Sciences of the United States of America, vol. 98, no. 11, pp. 5981-5985, 2001.

[15] K. Lewis and A. M. Klibanov, "Surpassing nature: rational design of sterile-surface materials," Trends in Biotechnology, vol. 23, no. 7, pp. 343-348, 2005.

[16] J. Lin, S. Qiu, K. Lewis, and A. M. Klibanov, "Bactericidal properties of flat surfaces and nanoparticles derivatized with alkylated polyethylenimines," Biotechnology Progress, vol. 18, no. 5, pp. 1082-1086, 2002.

[17] J. Lin, S. Qiu, K. Lewis, and A. M. Klibanov, "Mechanism of bactericidal and fungicidal activities of textiles covalently modified with alkylated polyethylenimine," Biotechnology and Bioengineering, vol. 83, no. 2, pp. 168-172, 2003.

[18] N. Hilal, V. Kochkodan, L. Al-Khatib, and T. Levadna, "Surface modified polymeric membranes to reduce (bio)fouling: a microbiological study using E. coli," Desalination, vol. 167, no. 1-3, pp. 293-300, 2004.

[19] N. Beyth, I. Yudovin-Farber, R. Bahir, A. J. Domb, and E. I. Weiss, "Antibacterial activity of dental composites containing quaternary ammonium polyethylenimine nanoparticles against Streptococcus mutans," Biomaterials, vol. 27, no. 21, pp. 3995-4002, 2006.

[20] I. Yudovin-Farber, N. Beyth, E. I. Weiss, and A. J. Domb, "Antibacterial effect of composite resins containing quaternary ammonium polyethyleneimine nanoparticles," Journal of Nanoparticle Research, pp. 1-13, 2009.

[21] I. Yudovin-Farber, N. Beyth, A. Nyska, E. I. Weiss, J. Golenser, and A. J. Domb, "Surface characterization and biocompatibility of restorative resin containing nanoparticles," Biomacromolecules, vol. 9, no. 11, pp. 3044-3050, 2008.

[22] T. Azzam, H. Eliyahu, L. Shapira, M. Linial, Y. Barenholz, and A. J. Domb, "Polysaccharide-oligoamine based conjugates for gene delivery," Journal of Medicinal Chemistry, vol. 45, no. 9, pp. 1817-1824, 2002.

[23] H. Hosseinkhani, T. Azzam, Y. Tabata, and A. J. Domb, "Dextran-spermine polycation: an efficient nonviral vector for in vitro and in vivo gene transfection," Gene Therapy, vol. 11, no. 2, pp. 194-203, 2004.

[24] C. Z. Chen, N. C. Beck-Tan, P. Dhurjati, T. K. van Dyk, R. A. LaRossa, and S. L. Cooper, "Quaternary ammonium functionalized poly(propylene imine) dendrimers as effective antimicrobials: structure-activity studies," Biomacromolecules, vol. 1, no. 3, pp. 473-480, 2000.

[25] E. F. Panarin, M. V. Solovskii, N. A. Zaikina, and G. E. Afinogenov, "Biological activity of cationic polyelectrolytes," Die Makromolekulare Chemie, vol. 9, pp. 25-33, 1985.

[26] A. Kanazawa, T. Ikeda, and T. Endo, "Polymeric phosphonium salts as a novel class of cationic biocides. X. Antibacterial activity of filters incorporating phosphonium biocides," Journal of Applied Polymer Science, vol. 54, no. 9, pp. 1305-1310, 1994.

[27] A. Kanazawa, T. Ikeda, and T. Endo, "Polymeric phosphonium salts as a novel class of cationic biocides. VII. Synthesis and antibacterial activity of polymeric phosphonium salts and their model compounds containing long alkyl chains," Journal of Applied Polymer Science, vol. 53, no. 9, pp. 1237-1244, 1994.

[28] A. Kanazawa, T. Ikeda, and T. Endo, "Polymeric phosphonium salts as a novel class of cationic biocides. VIII. Synergistic effect on antibacterial activity of polymeric phosphonium and ammonium salts," Journal of Applied Polymer Science, vol. 53, no. 9, pp. 1245-1249, 1994.

[29] P. H. Sellenet, B. Allison, B. M. Applegate, and J. P. Youngblood, "Synergistic activity of hydrophilic modification in antibiotic polymers," Biomacromolecules, vol. 8, no. 1, pp. 19 23, 2007. 

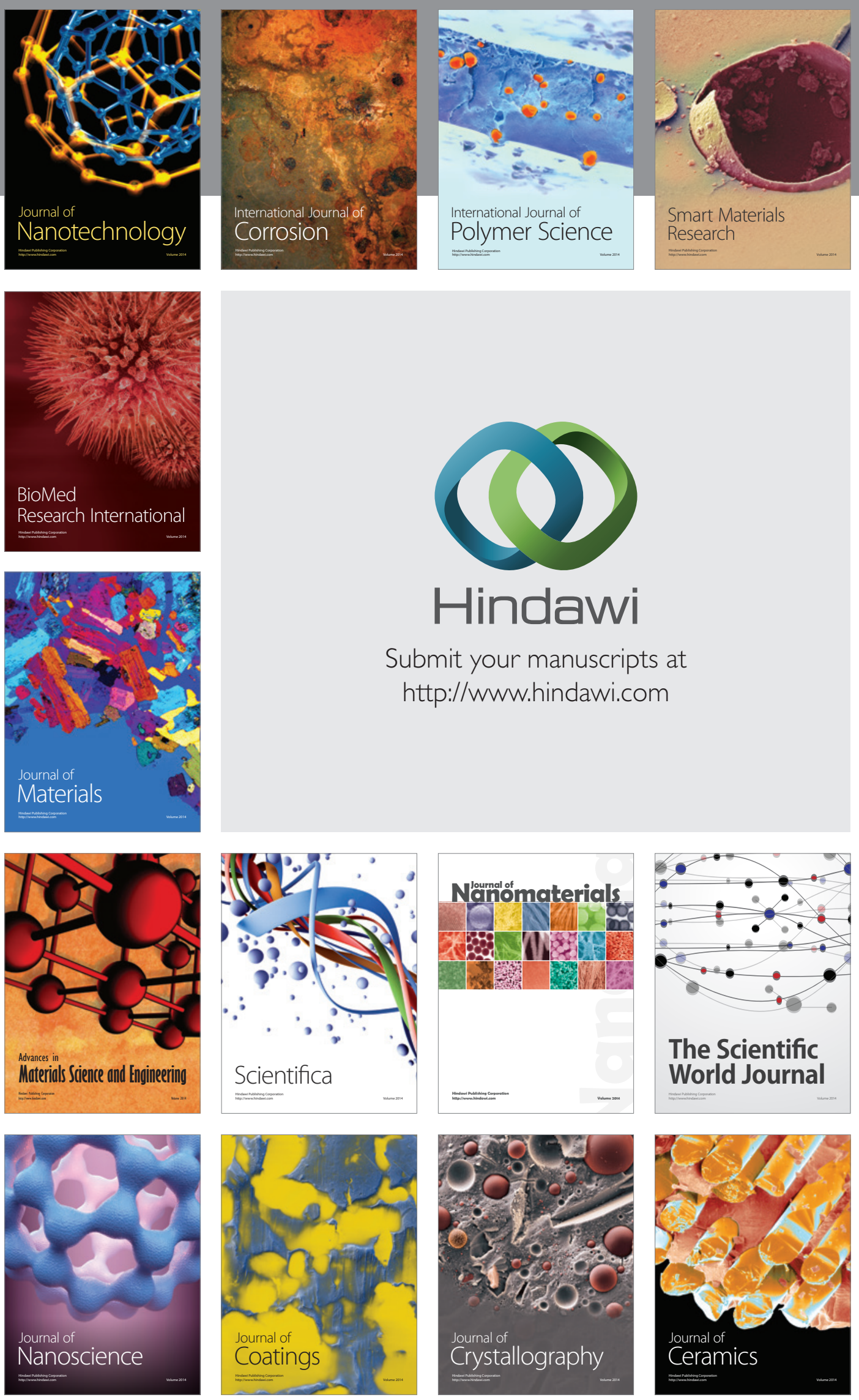

The Scientific World Journal

Submit your manuscripts at

http://www.hindawi.com

\section{World Journal}

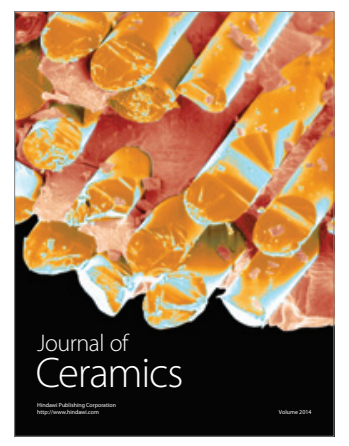

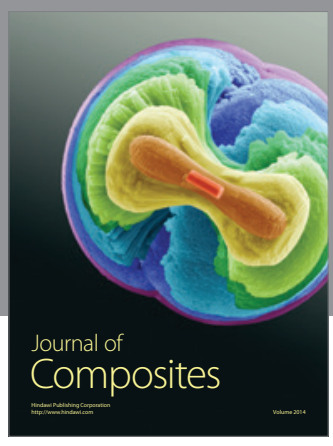
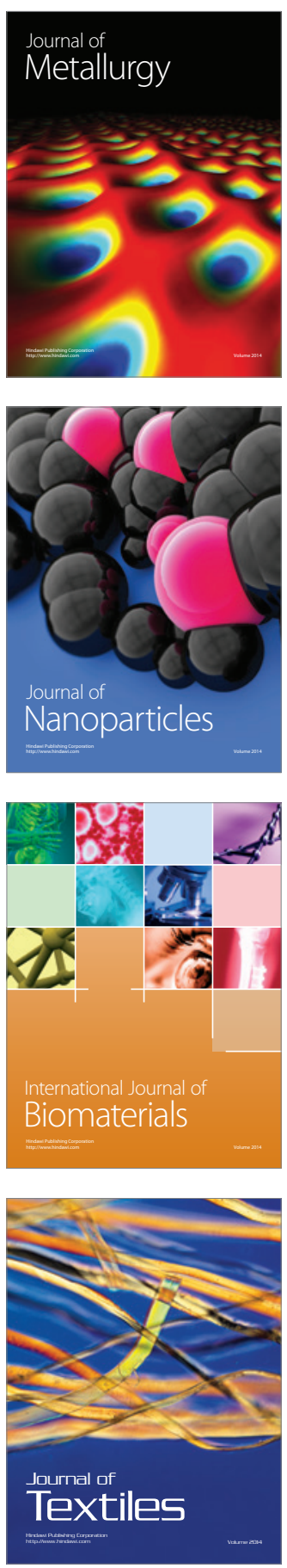